\begin{tabular}{ll}
\hline \hline MINING AND METALLURGY INSTITUTE BOR & ISSN: 2334-8836 (Štampano izdanje) \\
UDK: 622 & ISSN: 2406-1395 (Online) \\
\hline \hline
\end{tabular}

\author{
Nebojša Đokić, , Dragana Milenković, Nebojša Stošić, \\ Sanja Dobričanin*

\section{KNOWLEDGE ECONOMY AS A FACTOR OF COMPETITIVENESS OF THE REPUBLIC OF SERBIA ON A WAY TO THE THE EUROPEAN UNION}

\begin{abstract}
Knowledge, that is the obtained knowledge level of a certain community, its capacity to develop innovations, to adopt modern scientific and technological achievements, in other words, its capacity to create a new knowledge, which leads to further prosperity and development, is in the basis of competitiveness. Emphasizing knowledge and innovations as the main resources of developebment and relying on them in creating the competitiveness index surely leads to quality display of competitive capacities of a certain society which is the basis of this paper. Today, the Republic of Serbia is a candidate country for the EU membership and it is at an economic and social turning point, which brings the new challenges and chances. Just as it does for every European country, the European Union represents a basis for stable development and improvement of national competitiveness for Serbia.

Keywords: competitiveness, knowledge economy, competitiveness index, innovation
\end{abstract}

\section{INTRODUCTION}

Nowadays, in the knowledge era, the competitive advantage of an economy is based on technological development and innovativity, as well as using the potential chances and opportunities for realization which knowledge is necessary. Constant investment in the human capital increases the productivity, employment, and a direct source of innovaton and long-term competitiveness is obtained. Human resources and their knowledge represent a key to the success for economy and companies, while an incompetent workforce represents one of the most important obstacles in their business. Development of competitiveness on the domestic and foreign market has become an imperative for development a modern economy. Knowledge is a factor that generates the rapid changes. Changes are the condition for survival, thus it can be concluded that learning and training are, in fact, survival. For all these reasons, the modern management systems are based on changes, knowledge and constant learning. Human knowledge is a dynamic category that is constantly improved with development of science and technology directly resulting in a rapid obsolescence of the existing knowledge. "From the economic standpoint, with the function of gaining and improving an competitive advantage, as a prerequisite for development, the modern companies enable an efficient use of knowledge which can be seen in realization of innovations, at the same time decreasing the time required for its practical application" (Premovic, 2010).

\footnotetext{
* University of Pristina, Faculty of Economics, Kolasinska 156, 38220 Kosovska Mitrovica, Serbia,e-mail:djokic70@gmail.com
} 
Knowledge enables to the individual and community to cope in reality. Know-ledge is the awareness of the cause, functioning and anticipaton of events. Nowadays, the main role in the economy belongs to a worker with knowledge. Know-ledge is the basic instrument for creating wealth.

According to the National strategy of sustainable development, knowledge society and knowledge economy do not refer to rigid, that is textbook knowledge, but rather a set of skills, abilities and competences used for creating innovations, solving problems, cooperating with others and working with the aim of general well-being (Government of the Republic of Serbia, 2008).

In order for countries to be able to respond to the challenges of an economy based on knowledge, the following factors in the National strategy for sustainable development of Serbia are listed:

- modern education and permanent training;

- means for research and development, especially for investment in the modern industries (computers, biotechnology, pharmacology...);

- adequate scientific-technological and cultural policy of a society;

- adequate management of economic changes in accordance with the changes in the world and its close surroundings;

- choice of a macroeconomic policy, systematic and structural economic solutions;

- telecommunications, massive use of computers and other modern technical devices;

- High technology sectors and defining incentive measures for attracting foreign investments into those sectors;

- degree of ownership rights protection and especially of intellectual property and

- social responsibility of a company's business.
The strategic course of Serbia is its integration in EU and launching domestic companies and economy on the European and world market among competitors from a great number of successful, exportoriented companies from the other countries, multinational companies with world famous products - brands, modernorganized companies with the use of the most modern information technology and modern - designed organizational structures with very educated, professional and experienced management (Vesic, 2010).

\section{KNOWLEDGE ECONOMY - WHY AND HOW}

Knowledge is the basis for progress and development of a society. Investing in knowledge includes the costs of education, research and software. It is very complex to be measured. Managing investments in knowledge and measuring these investments have developed into one of the most important issues which knowledge economy is dealing with. Knowledge economy has resulted out of the rise of knowledge intensity and increasing globalization of economic affairs. The rise of knowledge intensity is mutually moved by the information revolution and technological changes that are moving rapidly. Globalization is moved by deregulation and revolution in communication related to the Internet. However, it is important to note that the term "knowledge economy" refers to not only any individual phenomenon, or their combination, but the overall economic structure which occurs nowadays. Investing in knowledge that increases economic efficiency and economic growth will enable technological development and set the basis for increasing employment (Albijanic, 2010).

By analyzing the world economy today and its basic features, Draskovic emphasizes that there are "three basic driving and strategic forces of modern economy: 
knowledge, changes and globalization" (Draskovic, 2010, pp. 83-90).

Improving the existing and introducing new products can be realized through the systematic and continuous implementation of processes for innovation and learning in companies. "Innovation in the knowledge economy is not only the process of creating the new products. In essence, it is an element of production and other business processes because a company either realizes innovations or it disappears" (Krstic, Petrovic, 2010, pp. 215-225). Knowledge and effective management of organizational knowledge encourages creativity of employees that is realized through various innovations. The ability to innovate is one of the important factors of change and success, which is why innovation is a necessity for the survival and vitality of companies and for the national economies and whole society (Premovic et al., 2011).

Knowledge economy is formed and spread through the basis of knowledge as a unique, unlimited and individual factor of production that cannot be substituted by the other resources. This same knowledge is converted into the economic goods and income in most economic activities, not only in those which are conditionally associated with the advanced technologies. In the knowledge economy, innovations are not only reserved for the new products and technologies, but are also of value for the new ways of organization and, therefore, for mutual relationships with customers. Innovations are a precondition for the company's competitiveness and whole economy, where knowledge enables the sustainable economic growth and development (Figure 1).

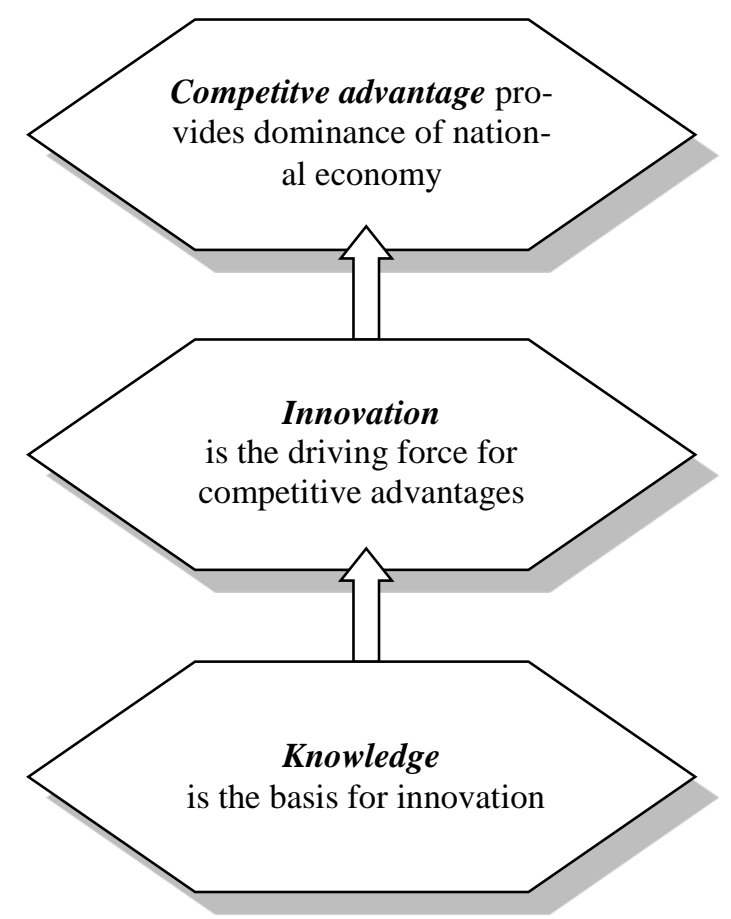

Figure 1 Knowledge as the source of competitive advantage (Albijanic, 2010, p. 56) 
In order for knowledge economy to evolve towards a higher development level, it is necessary to create the conditions for compromise, equal and joint membership of countries into the global economy. Of course, knowledge here occurs as a necessary corrective of neoliberal globalization and precondition for the reconstruction of mankind. Only then, we will have an intelligent, sustainable and inclusive economy.

\section{LEADING GOALS OF THE "EUROPE 2020" STRATEGY}

The "Europe 2020" strategy, which entered into force in 2011, also focuses on the competitiveness which recognizes knowledge as one of the three crucial pillars of development (Kronja, 2011).

The Lisbon agenda, in many respects, represented a decisive step in the EU access to the social and economic development. There are open tensions, which must be dealt with by the EU protagonists in the near future. First of all, the tensions are related to the political and economic establishment of the EU and reform of the European society model in the global economy. The Lisbon agenda presented the first attempt at finding a new compromise through a clear Strategy (Natali, 2010).

Investing in knowledge is of crucial importance for research and development. The Lisbon strategy (Kronja, 2011, p.12) was started as a response to globalization. The idea was for the EU and member countries to cooperate in reforms, the aim of which is to enable growth and more jobs by investment in the intellectual capital and technological development and, in that way, overcome recession and transform the EU into a more innovative, sustainable and greener economy. The EU has revised the growth strategy for the period after 2010 by intro- ducing more reforms at all levels. The new strategy tends to aid EU in overcoming the crisis and movement towards a society based on knowledge (Kronja, 2011).

Three crucial initiators of growth are the basis for a new strategy and they should be used through the specific activities at the national level and level of the EU: intelligent, sustainable and inclusive growth. The leading goals of the Europe 2020 Strategy can be seen in Table 1. The leading integrated guidelines for Europe until 2020 are:

1. Quality assurance and providing longterm sustainability of public finances,

2. Removal of macroeconomic disbalances,

3. Removing the disbalance in Eurozone,

4. Optimization of research and development and investment in innovation; strengthening the knowledge triangle and releasing the potential of a digital economy,

5. More efficient use of resources and reducing gas emissions which cause the greenhouse effect,

6. Improving the basic conditions for companies and consumers and modernization of the industrial base,

7. Increasing the employment rate and removing structural unemployment,

8. Educating workforce, the qualifications of which match the demands of the labour market, improving the quality of jobs and learning throughout life,

9. Increasing the efficiency of general education and training at all levels and facilitating access to the higher education institutions,

10. The fight against exclusion and poverty (Vukovic, 2011, p.507). 
Table 1 Leading goals of the Europe 2020 Strategy (Vukovic, 2011, p.500)

\section{LEADING GOALS}

To increase the employment rate of 20-64 year olds from current $69 \%$ to at least $75 \%$.

To invest 3\% GDP into research and development; primarily, to improve conditions for investment of the private sector into research and development; also, to develop a new indicator for the assessment of innovativity.

To reduce gas emissions which cause the greenhouse effect for at least $20 \%$ in comparison to 1990 , that is $30 \%$ if the conditions permit so.

To increase the share of renewable energy in consumption to $20 \%$, as well as energetic efficiency for $20 \%$. To reduce the rate of students leaving school from current $15 \%$ to $10 \%$; to increase the share of 30-34 year olds with a college diploma from $31 \%$ to at least $40 \%$.

To reduce the number of Europeans who live below the national poverty line for $25 \%$, which would lift 20 million peple out of poverty.*

\begin{tabular}{|c|c|c|}
\hline $\begin{array}{c}\text { INTELLIGENCE } \\
\text { GROWTH }\end{array}$ & SUSTAINABLE GROWTH & $\begin{array}{l}\text { INTEGRATIVE } \\
\text { GROWTH } \\
\end{array}$ \\
\hline $\begin{array}{l}\text { Innovations } \\
\text { The EU initiative "Innovation } \\
\text { Union" which improves the } \\
\text { main conditions and availa- } \\
\text { bility of financial funds for } \\
\text { research and development, } \\
\text { with the aim of strengthening } \\
\text { the innovation chain and } \\
\text { increase investements by the } \\
\text { Union. }\end{array}$ & $\begin{array}{l}\text { Climate, energy and mobility } \\
\text { The EU initiative "Europe } \\
\text { resource efficiency" needs to } \\
\text { contribute to separating eco- } \\
\text { nomic growth from using re- } \\
\text { sources by decarbonizing the } \\
\text { economy, intensifying the use } \\
\text { of renewable energy, modern- } \\
\text { izing traffic and improving } \\
\text { energy efficiency. }\end{array}$ & $\begin{array}{l}\text { Employment and qualifica- } \\
\text { tions } \\
\text { The EU initiative "Agenda for } \\
\text { new employment qualifica- } \\
\text { tions and opportunities" } \\
\text { should modernize the labour } \\
\text { market by facilitating mobility } \\
\text { of the employed and acquiring } \\
\text { qualifications throughout life, } \\
\text { with the aim of increasing the } \\
\text { employment rate and better } \\
\text { compliance of supply and } \\
\text { demand on the labour market. }\end{array}$ \\
\hline $\begin{array}{l}\text { Education } \\
\text { The EU initiative "Youth on } \\
\text { the move" which improves } \\
\text { the education systems and } \\
\text { makes the European universi- } \\
\text { ties more attractive for stu- } \\
\text { dents from the whole world. }\end{array}$ & \multirow{2}{*}{$\begin{array}{l}\text { Competitiveness } \\
\text { The EU initiative "Industrial } \\
\text { policy in the globalization era" } \\
\text { should imrove the business } \\
\text { environment, especially fo } \\
\text { small and medium size compa- } \\
\text { nies and build a strong and } \\
\text { sustainable industrial structure } \\
\text { which is competitive on the } \\
\text { international market. }\end{array}$} & \multirow{2}{*}{$\begin{array}{l}\text { Fight against poverty } \\
\text { The EU initiative "European } \\
\text { platform for the fight against } \\
\text { poverty" provides the social } \\
\text { and territorial cohesion in } \\
\text { order for everyone to benefit } \\
\text { from growth and employ- } \\
\text { ment, and the people who live } \\
\text { in poverty and social exclu- } \\
\text { sion can actively participate } \\
\text { in social life. }\end{array}$} \\
\hline $\begin{array}{l}\text { Digital society } \\
\text { The EU initiative "Digital } \\
\text { agenda for Europe agenda za } \\
\text { Evropu“ which accelerates the } \\
\text { spreading of fast Internet and } \\
\text { provides households and } \\
\text { companies with the advan- } \\
\text { tages of digital unique market. }\end{array}$ & & \\
\hline
\end{tabular}

* The national poverty limit is defined as $60 \%$ median of available national income in every member country

In a function of research, Table 2 offers an outline of ranking the countries in transition towards the realized progress in relation to the priorities determined by the "Strategy 2020". 
Table 2 Ranking of countries in transition towards the priorities determined by the "Strategy 2020"

\begin{tabular}{|l|c|c|c|c|c|c|c|}
\hline \multirow{2}{*}{ Country } & \multicolumn{4}{|c|}{ Intelligence growth } & \multicolumn{2}{c|}{ Integrative growth } & $\begin{array}{c}\text { Sustainable } \\
\text { growth }\end{array}$ \\
\cline { 2 - 8 } & $\begin{array}{c}\text { Company } \\
\text { environ- } \\
\text { ment }\end{array}$ & $\begin{array}{c}\text { Digital } \\
\text { agenda }\end{array}$ & $\begin{array}{c}\text { Innovative } \\
\text { Europe }\end{array}$ & $\begin{array}{c}\text { Education } \\
\text { and train- } \\
\text { ing }\end{array}$ & $\begin{array}{c}\text { Labour } \\
\text { market and } \\
\text { employment }\end{array}$ & $\begin{array}{c}\text { Social } \\
\text { inclusion }\end{array}$ & $\begin{array}{c}\text { Environment } \\
\text { protection }\end{array}$ \\
\hline Sweden & 5,05 & 6,13 & 6,12 & 5,75 & 4,65 & 6,40 & 6,31 \\
\hline Croatia & 3,30 & 4,72 & 3,14 & 4,27 & 3,55 & 4,24 & 4,83 \\
\hline Estonia & 4,13 & 5,94 & 4,07 & 5,03 & 4,66 & 4,66 & 4,67 \\
\hline $\begin{array}{l}\text { FYR of } \\
\text { Macedonia }\end{array}$ & 3,70 & 4,72 & 2,72 & 3,84 & 3,98 & 3,36 & 3,47 \\
\hline Hungary & 3,61 & 4,60 & 3,53 & 4,51 & 3,97 & 4,52 & 3,70 \\
\hline Lithuania & 5,33 & 5,35 & 3,49 & 4,81 & 4,69 & 3,75 & 4,59 \\
\hline Montenegro & 3,95 & 4,74 & 3,62 & 4,37 & 4,67 & 4,79 & 4,60 \\
\hline Poland & 3,65 & 4,44 & 3,39 & 4,89 & 4,01 & 3,97 & 4,20 \\
\hline Romania & 3,44 & 4,08 & 2,89 & 4,14 & 4,00 & 4,03 & 3,97 \\
\hline Serbia & 3,12 & 4,10 & 2,79 & 3,81 & 3,53 & 3,85 & 3,49 \\
\hline Slovenia & 3,73 & 4,88 & 4,08 & 4,95 & 4,26 & 5,19 & 5,04 \\
\hline Turkey & 3,90 & 4,27 & 3,29 & 4,01 & 3,42 & 4,01 & 3,32 \\
\hline
\end{tabular}

Source: WEF; The Europe 2020 Competitiveness Report: Building a More Competitive Europe, Edition 2012.

This battle for growth and jobs requires the accepting strategies at all levels and mobilization of all actors throughout Europe. On its way towards EU, Serbia must harmonize its development strategy with those demands if it wants to join the EU family. Europe is reducing the innovation gap in comparison to USA and Japan, but the differences in terms of success among the EU member countries are still great. The innovative and technological gap is increasing at a regional level: success in the innovation area has worsened in almost $20 \%$ of EU regions. This development is measured in knowledge indexes that describe the knowledge competitiveness. Namely, there are 23 composite indexes which define the competitiveness of an economy and they include the knowledge parametres. It has been noted that they can be classified into four categories (Katic et al., 2012, p.32):

1. Competitiveness indexes,

2. Knowledge competitiveness indexes,
3. Innovativity competitiveness indexes, and

4. Information-communication technologies competitiveness indexes

The mentioned knowledge indexes KEI, KI and IKT can be seen in Table 3 and in Figure 2 where data for the basic pillars of these indicators is presented.

Countries that realized the biggest shift are Estonia and Lithuania. The total progress was contributed by the openness and attraciveness of the EU research system, cooperation in the area of business innovations and knowledge commercialization, which is visible from income from permits and patents of abroad. However, the growth of public expenditures related to research and development is neutralized by the reduction in investment of venture capital and business investments in innovations, which are not in the area of research and development. 
Table 3 Ranking of the leading countries in transition towards indexes KEI and KI

\begin{tabular}{|c|l|c|c|c|c|c|c|}
\hline Ranking & \multicolumn{1}{|c|}{ Country } & KEI & KI & EIR & Innovation & Education & IKT \\
\hline- & Sweden & 9.43 & 9.38 & 9.58 & 9.74 & 8.92 & 9.49 \\
\hline 1 & Estonia & 8.40 & 8.26 & 8.81 & 7.75 & 8.60 & 8.44 \\
\hline 2 & Czech Republic & 8.14 & 8.00 & 8.53 & 7.90 & 8.15 & 7.96 \\
\hline 3 & Hungary & 8.02 & 7.93 & 8.28 & 8.15 & 8.42 & 7.23 \\
\hline 4 & Slovenia & 8.01 & 7.91 & 8.31 & 8.50 & 7.42 & 7.80 \\
\hline 5 & Lithuania & 7.80 & 7.68 & 8.15 & 6.82 & 8.64 & 7.59 \\
\hline 6 & Slovakia & 7.64 & 7.46 & 8.17 & 7.30 & 7.42 & 7.68 \\
\hline 7 & Latvia & 7.41 & 7.15 & 8.21 & 6.56 & 7.73 & 7.16 \\
\hline 8 & Poland & 7.41 & 7.20 & 8.01 & 7.16 & 7.76 & 6.70 \\
\hline 9 & Croatia & 7.29 & 7.27 & 7.35 & 7.66 & 6.15 & 8.00 \\
\hline 10 & Romania & 6.82 & 6.63 & 7.39 & 6.14 & 7.55 & 6.19 \\
\hline 11 & Bulgaria & 6.80 & 6.61 & 7.35 & 6.94 & 6.25 & 6.66 \\
\hline 12 & Serbia & 6.02 & 6.61 & 4.23 & 6.47 & 5.98 & 7.39 \\
\hline 13 & Russia & 5.78 & 6.96 & 2.23 & 6.93 & 6.79 & 7.16 \\
\hline 14 & Ukraine & 5.73 & 6.33 & 3.95 & 5.76 & 8.26 & 4.96 \\
\hline 15 & FYR Macedonia & 5.65 & 5.73 & 4.99 & 5.15 & 6.74 & - \\
\hline
\end{tabular}

Source: The World Bank; KEI and KI Indexes (KAM 2012);

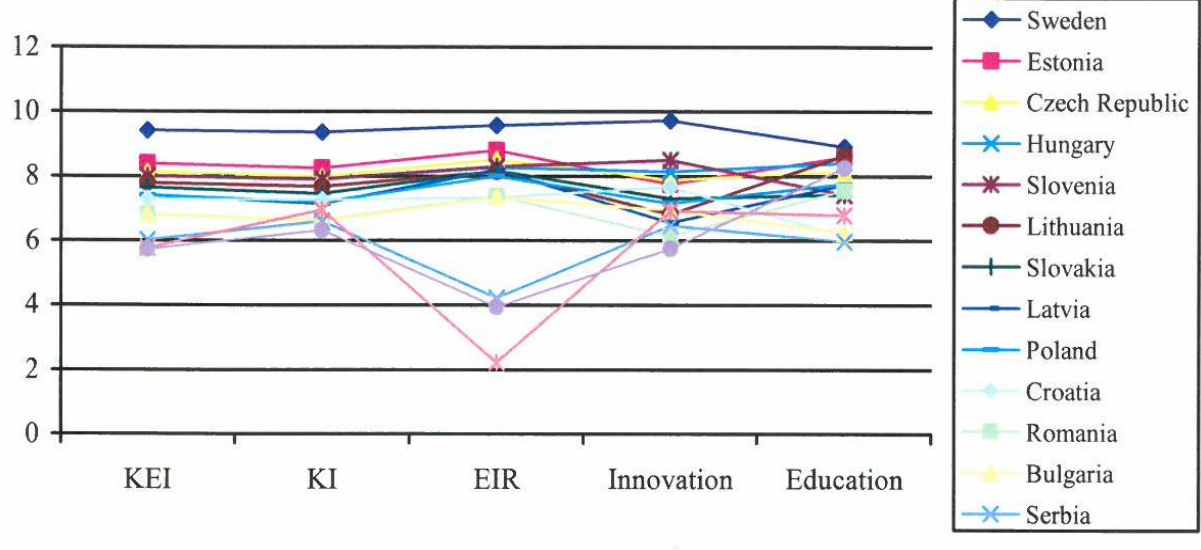

Figure 2 Ranking of the leading countries towards the KEI and KI indexes

Table 4 and Figure 3 show a comparison of the global competitiveness index and innovativity in the leading countries of the world for the period 2012-2013. 
Tabela 4 Comparison of competitiveness ranking (GCI) and innovativeness ranking for 2012-2013

\begin{tabular}{|l|c|c|c|c|}
\hline \multirow{2}{*}{ Country } & \multicolumn{2}{|c|}{ GCI 2012-13 } & \multicolumn{2}{c|}{ Innovativity } \\
\cline { 2 - 5 } & Ranking & Results & Ranking & Results \\
\hline Switzerland & 1 & 5.67 & 1 & 5.72 \\
\hline Singapore & 2 & 5.61 & 13 & 5.14 \\
\hline Finland & 3 & 5.54 & 2 & 5.65 \\
\hline Germany & 4 & 5.51 & 4 & 5.59 \\
\hline USA & 5 & 5.48 & 6 & 5.43 \\
\hline Sweden & 6 & 5.48 & 5 & 5.46 \\
\hline Hong Kong & 7 & 5.47 & 7 & 4.83 \\
\hline Netherlands & 8 & 5.52 & 7 & 5.36 \\
\hline Japan & 9 & 5.40 & 3 & 5.62 \\
\hline Great Britain & 10 & 5.37 & 10 & 5.15 \\
\hline
\end{tabular}

Source: Schwab, K., World Economic Forum, The Global Competitiveness Report 2013-2014

"Realization of innovations throughout Europe is still a priority if we want at least $20 \%$ of GDP of EU to come from production by 2020, which is the goal of our industrial policu. The key to growth is more business investments, greater demand for the European innovation solutions and a reduced number of obstacles to the innovation commercialization. We need the innovative companies and a framework adapted to a growth so that the innovations can be successfully launched onto the market" (Tijanic, 2014).

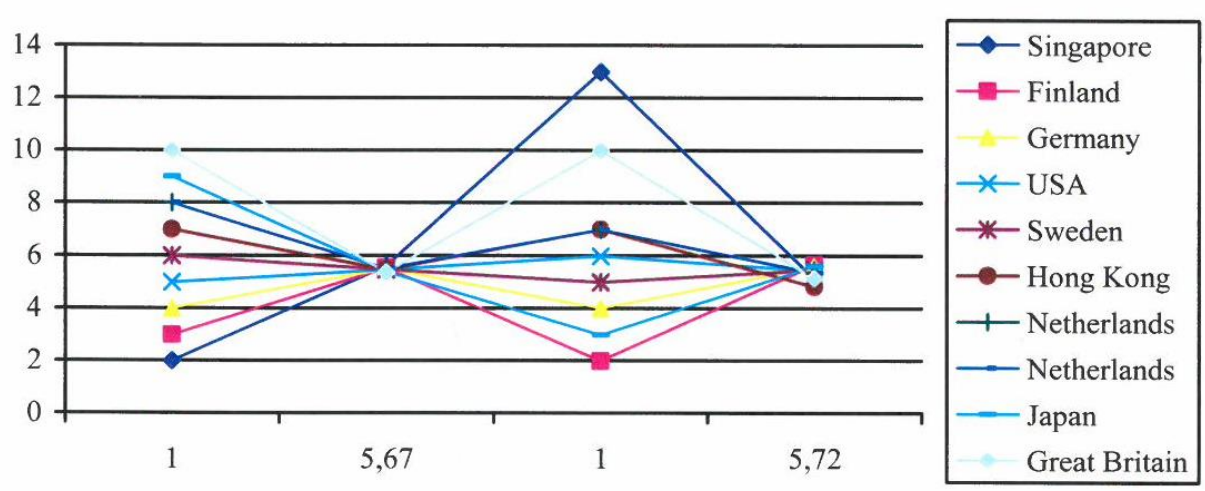

Figure 3 Comparison of the ranking of competitiveness (GCI) and innovativity of the leading countries in the world for 2012-2013

The main obstacle for development of Serbia is a bad macroeconomic environment -deepened budget deficit, reduction of national savings and increase of the public debt. For years, Serbia has been at the bottom of al competitiveness list, which is certainly a precondition for the pessimistic attitudes of businessmen. 


\section{SERBIA AND THE GLOBAL COMPETITIVENESS INDEX}

WEF measures the quality and competitiveness of the business environment in 148 countries of the world by the Global Competitiveness Index. The GCI is obtained by analyzing more than 110 indicators, based on a research of the main managers'attitudes in the countries included in the research and reports of other international organizations, such as the World Bank and its Report on the facility of doing business. In the WEF report for 2013 , Serbia takes only the $101^{\text {st }}$ position in competitiveness, which is a fall for 6 spots when compared to the previous year and a worse result in comparison to all countries in the region, including Albania $\left(95^{\text {th }}\right.$ place), Bosnia and Herzegovina $\left(87^{\text {th }}\right.$ position), Croatia ( $75^{\text {th }}$ position), FYR Macedonia $\left(73^{\text {rd }}\right.$ position), Montenegro $\left(67^{\text {th }}\right.$ position) and Hungary (63 ${ }^{\text {rd }}$ position) ( $w w w . d w . d e / z a s t o j-u$-reformama).

Serbia has improved its position on the global competitiveness list of WEF for 2014 for seven spots and taken the $94^{\text {th }}$ positioon among 144 countries. The jump from $101^{\text {st }}$ position on the list for 2013 Serbia noted, based on the increase in the value of the GCI from 3.8 to 3.9 , as stated in the report published by the Foundation for Development of Economics (FREN) as a partner o WEF (World Economic Forum, The Global Competitiveness Report 2013-2014). The most competitive country in the world is Switzerland; Finland and Germany are leaders in the EU and on the Western Balkans, the leader is the FYR Macedonia. The value of the GCI ranges from 1 to 7 , where 1 is the worst and 7 the best mark (www.istmedia.rs/srbijaje-manje-konkurentna-od-clanica-evropskeunije). According to the results for 2014, Serbia has repeated the historically largest value of the GCI, which is the result of the current perception of the business world about the capacity of a country to provide a longterm stable economic growth, as stated in the report. The biggest index value of 3.9 was realized by Serbia shortly before the first wave of the crisis in 2008. The value of GCI notably dropped to 3.77 the following year, in 2009 and after that, there was a period of gradual recovery of the index. Serbia is in the category of institutions on the $122^{\text {nd }}$ position with the index 3.2 ; according to the infrastructure, it is on the $77^{\text {th }}$ position (index 3.9 ); according to the macroeconomic environment, it is on $129^{\text {th }}$ position (index 3.5) in the world and in the healthcare and elementary education on the $68^{\text {th }}$ position with an index of 5.8. According to the criteria higher education and training, Serbia takes the 74th position on the list (4.3), and in the efficiency of the goods market - position 128 (3.8), efficiency of the labour market - position 119 (3.7), sophistication of the financial market - position 109 (3.5), technological readiness - position 49 (4.4), and according to the size of the market - position 71 (index 3.7). According to the sophisticaiton of the business processes, Serbia takes the $132^{\text {nd }}$ position (indeks 3.2) among 144 countries on the list and according to the innovations position 108 (index 2.9) (Table 5).

According to the ranking on the list of competitiveness for 2014, among countries of the West Balkans, the only country that has a worse ranking than Serbia is Albania, with the $97^{\text {th }}$ position. Its index is 3.84. The FYR Macedonia is the best ranked, at the $63^{\text {rd }}$ position, with an index of 4.26. It has jumped 10 spots on the list. Montenegro kept the $67^{\text {th }}$ position. Based on the position of GCI basic value of 4.23 , Slovenia takes the $70^{\text {th }}$ position. The position (fall for 8 spots) with the index value of 4.22 was noted, while Croatia is on the $77^{\text {th }}$ position according to competitiveness, two spots lower than in 2013. 
Table 5 The most important indicators of competitiveness of the Republic of Serbia

\begin{tabular}{|l|c|c|}
\hline Indicators & Position & Index \\
\hline Institutions & 122 & 3.2 \\
\hline Infrastructure & 77 & 3.9 \\
\hline Macroeconomic environment & 129 & 3.5 \\
\hline Health an elementary education & 68 & 5.8 \\
\hline Higher education and training & 74 & 4.3 \\
\hline Efficiency of the goods market & 128 & 3.8 \\
\hline Efficiency of the labour market & 119 & 3.7 \\
\hline Sophistication of the financial market & 109 & 3.5 \\
\hline Technological readiness & 49 & 4.4 \\
\hline Market size & 71 & 3.2 \\
\hline Sophistication of business processes & 132 & 3.2 \\
\hline Innovativity & 108 & 2.9 \\
\hline
\end{tabular}

Source: adapted according to the report of WEF for 2013-14.

With the GCI value of 4.13 , Bosnia and Herzegovina was not ranked on the list for 2014 because of inability to collect data. In 2013 it was on the $87^{\text {th }}$ place, with an index of 4.02 (Table 6 and Figure 4).

In the EU, there is still a gap between a very competitive north, on one hand, and south and east which are behind in competition, but there is a new classification among countries that perform the reforms and the ones which do not. Several countries greatly influenced by the economic crisis, such as Spain, Portugal and Greece, have made a significant progress in terms of improvement the funcioning of its markets and allocation of product resources In the SEF report for 2014-2015, Spain is on the $35^{\text {th }}$ position, where it used to be in 2013-2014 too, when the list included four more countries than today. Portugal is on the $36^{\text {th }}$ position in compariso to the $51^{\text {st }}$ from the previous year and Greece is on the $81^{\text {st }}$, which is ten spots higher than in the year before.

Table 6 The absolute ranking of the former Yugoslav countries for the period 2007-2014

\begin{tabular}{|l|c|c|c|c|c|c|}
\hline Ranking & Slovenia & Montenegro & FYR Macedonia & Croatia & B\&H & Serbia \\
\hline $\mathbf{2 0 1 4}$ & $\mathbf{7 0}$ & $\mathbf{6 7}$ & $\mathbf{6 3}$ & $\mathbf{7 7}$ & - & $\mathbf{9 4}$ \\
\hline $\mathbf{2 0 1 3}$ & 62 & 67 & 73 & 75 & 87 & 101 \\
\hline $\mathbf{2 0 1 2}$ & 56 & 72 & 80 & 81 & 88 & 95 \\
\hline $\mathbf{2 0 1 1}$ & 57 & 60 & 79 & 76 & 100 & 94 \\
\hline $\mathbf{2 0 1 0}$ & 45 & 49 & 79 & 77 & 102 & 96 \\
\hline $\mathbf{2 0 0 9}$ & 37 & 62 & 84 & 72 & 109 & 93 \\
\hline $\mathbf{2 0 0 8}$ & 42 & 65 & 89 & 61 & 107 & 85 \\
\hline $\mathbf{2 0 0 7}$ & 39 & 82 & 94 & 57 & 106 & 91 \\
\hline
\end{tabular}

Source: Adapted according to the Neighbour countries more competitive than Serbia, GCI Global Competitiveness Index - Rank 


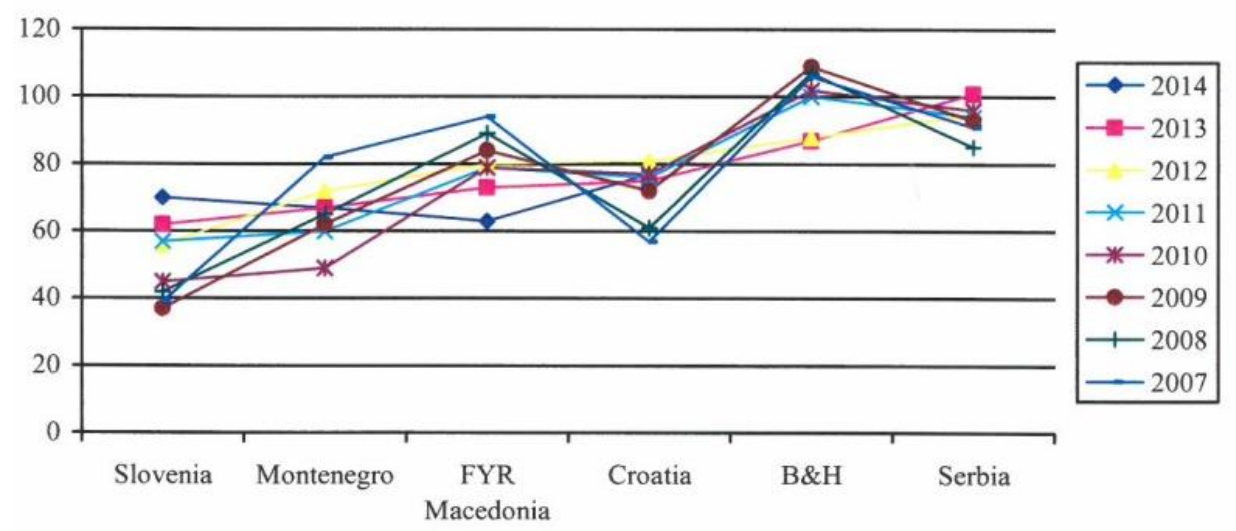

Figure 4 Competitiveness of the formerYugoslav countries for the period of 2007-2014

The most competitive countries in the EU are Finland and Germany. Both countries have fallen on the list for one spot, so Finland is now the fourth in the world and Germany is the fifth. Generally, Finland has a good performance in all areas and a small fall on the world list is mainly the consequence of weakening the macroeconomic opportunities. In addition, according to the SEF, a small fall of Germany is a consequence of fear about the institutions and infrastructure, which has only partially recovered the improvement of the macroeconomic environment and financial development. The German education system received the worse marks than earlier. Great Britain improved for one spot and it is now in the ninth position. The performances of that country have improved owing to the results which arouse from a lower fiscal deficit and public debt. Britain still benefits from an efficient labour market and high level of financial development (Lojpur, Peković, 2013, pp.6175). The first position in the world for competitiveness and the highest index value of 5.7 in 2014 is held by Switzerland, while the worst value of 2.79 and the $144^{\text {th }}$ position is held by Guinea and pushed Chad one spot up. The order of the leading three on the list is slightly changes in comparison to 2013. Switzerland and Singapore were joined by the USA on the top of the list and, by doing so, passed Finland and Germany. Russia is the $53^{\text {rd }}$, which is ten spots better than in 2013, China is the $28^{\text {th }}$, Turkey is the $45^{\text {th }}$, Brazil is the $57^{\text {th }}$ and India is the $71^{\text {st }}$.

\section{SERBIA ON THE WAY TOWARDS THE EU}

The Republic of Serbia is going to encounter many challenges on the way to the EU. In order for Serbia to join a supranational community of countries such as the EU, based on a combination of international agreements, practices which must be respected and bodies which control the EU behaviour, it needs to carefully prepare. Serbia will not be able to become a part of the great European family until it meets all the criteria for joining the EU. Even if it could skip some phases that all countries of the EU passed, and be accepted in the Union for a shorter time period - it would return to as a boomerang. In fact, the effects of rapid acceptance would be in many ways negative. The economic consequences for the country would exceed the wish itself to join the European Union. 
If we compare the goals set by the EU and Serbia for the period of 2010-2020, we can see that they differ in many respects taht can be seen in Table 7 .
Based on the results, it can be seen that the Republic of Serbia is ten years behind the European Union (Milicevic, 2014, p.120).

Table 7 Priorities of the European Union and Serbia for the period 2010-2020

\begin{tabular}{|l|c|c|c|c|}
\hline \multirow{2}{*}{} & \multicolumn{2}{|c|}{$\begin{array}{c}\text { EUROPEAN } \\
\text { UNION }\end{array}$} & \multicolumn{2}{c|}{$\begin{array}{c}\text { REPUBLIC OF } \\
\text { SERBIA }\end{array}$} \\
\cline { 2 - 5 } & $\mathbf{2 0 1 0}$ & $\mathbf{2 0 2 0}$ & $\mathbf{2 0 1 0}$ & $\mathbf{2 0 2 0}$ \\
\hline Employment of population from 20-64 (\%) & 68 & 75 & 49 & 65 \\
\hline Investments in research and development (\%GDP) & 1.9 & 3 & 0.3 & 2.0 \\
\hline $\begin{array}{l}\text { Participation of energy use from the renewable sources } \\
\text { in the total energy use (\%) }\end{array}$ & 16 & 20 & 12 & 18 \\
\hline Energy efficiency (that is /1000\$ BDP-a) & 0.21 & 0.17 & 0.96 & 0.57 \\
\hline Population of 30-34 who have a university diploma (\%) & 31 & 40 & 21 & 30 \\
\hline $\begin{array}{l}\text { Poverty rate (below 60\% median of the available } \\
\text { population income) }\end{array}$ & 16 & 12 & 17 & 14 \\
\hline
\end{tabular}

Source: Serbia 2020: The development concept of the Republic of Serbia until 2020, 2010, p.3

Joining the European Union represents a significant incentive for the rapid economic growth and creation the new jobs. The previous experience shows that all countries which joined the EU, after a longer or shorter time period, entered a phase of dominant economic growth. In that context, funds which Serbia would receive as a developing country are of great importance. Free performance on the market of EU would present a great incentive for the development of some economy branches, such as the textile industry, agriculture, food industry, construction and the like. Of course, at the same time this presents a potential danger, having in mind that a number of producers could not keep up with the competition of the other producers from the EU.

\section{CONCLUSION}

For Serbia, there is no simple or fast way to remove the numerous and big determinants of incompetitiveness because the creation of competitive advantages needs a lot of time, investment and knowledge.
The Republic of Serbia is on a development intersection, which means that it is necessary to change the concept of development and system in which it is being realized. In the following development phase, Serbia needs to build an open, competitive economy, based on knowlede, which implies strengthening of institutions as crucial factors of competitiveness and development which enable the growth of resource quantity and the technology level and the growth og the range and quality of products and services. The disfunctional and undeveloped legal and institutional order in Serbia presents a great development limitation. The system is missing many laws, institutions of capital markets and, up to very recently, the international standards of accounting reports, a fast and efficient bankruptcy proceedings and so on. For the growth of competitiveness of the Serbian economy, system machanisms for stimulating and mobilizing the savings and credibility of the financial institutions are of special significance. They should contribute the company's competitiveness growth and the economy's as a whole. The central 
problem of Serbia on the way to the EU is incompetitiveness of the economy and financial sector and incomepetence of the public sector. Timely and high quality preparation of Serbia for the entrance in the European Union requires building a competitive market economy. Being very late when compared to the developed countries and successful countries in transition, which have become the members of the European Union, Serbia needs to adapt the strategy of its development to a new developmental and tehnological paradigm. In the other words, the Republic of Serbia should accept the new developmental and technological paradigm and change the previous development strategy and previous production-technologial, social and institutional system, with the aim of establishing an innovative environment and innovative behaviour and for all decisions, initiatives and activities to contribute to the creation of an innovative economy and knowledge society.

The main goals of knowledge economy in the Republic of Serbia are:

a) increasing the competitivenes of the economy,

b) joining the European integrations and

c) developing sectors and products which can be more intensive with knowledge and technology.

\section{REFERENCES}

[1] Albijanic M., Knowledge as a Source of Competitive Advantage, Singidunum University, Faculty of Economics, Finance i Administration, Belgrade, 2010.

[2] Vesic D., Influence of business globalization on the economic system of Serbia, Ministry of Economy of Serbia, Vol. LXII, br. 1, 2010, pp. 136-164.

[3] Government of the Republic of Serbia, National Strategy of Sustainable
Development, The economy of the Republic of Serbia - the sustainability of knowledge-based, knowledge-based economy - how and why ?, Official Gazette of RS ", 2008, No. 55/05.

[4] Draskovic M., Knowledge as an unlimited resource and facility management, Montenegrin Journal of Economics, 2010, No. 11, Vol. VI, p. 84.

[5] Djeric D., Reports of the World Bank and the World Economic Forum's competitiveness as a marke-ting tool of location, Annals of business economics in the year, 2013, Vol. 1, No 8, pp. 45-62.

[6] World Economic Forum, The Global Competitiveness Report 2013-2014. K., Schwab, Full Data Edition, pp.15-20.

[7] http://www.dw.de/zastoj-u-reformamako\%C4\%8Di-svetsku-privredu/a17897252

[8] Katic A., Cosic I., Andjelic G., Raletic S., Review of Competitiveness Indices that Use Komwledge as a Criterion, Acta Polytechnica Hunga-rica, 2012, Vol. 9, No 5, pp.25-44.

[9] Kronja J., The path of the Lisbon Strategy to the Strategy of Europe 2020, Guide to Europe 2020 Strategy, The Open Society Fund Serbia, 2011, p. 12

[10] Krstic B., Petrovic B., Improving the System of Measuring InnovationsPrerequisite to the Effective Guidance of Regional Development and Strengthen the Competitiveness of the Economy, Proceedings of the XV Inernational Scentific Meeting; Regional Development and Demographic Trends of Southeast Europe Nis, 2010, pp. 215-225.

[11] Lojpur A., Pekovic C., Knowledge and Innovation Policy in Transition Countries as a Measure of Readiness to Join the EU, Economics\&Economy, 2013, Vol. 1, No 2., pp. 61-75. 
[12] Milicevic V., Milicevic Z., Arsic Lj., Premovic J., Innovation and Knowledge as Generators of Economic Development of the Republic of Serbia, Inernational Scentific Conference Innovations in Function of Economy, Faculty of Applied Menagement, Economics i Finansce, Belgrade, 2014, pp. 119-124.

[13] Natali D., "The Lisbon Strategy, Europe 2020 and the Crisis in between", p. $93-113$, in E. Marlier \& D. Natali (eds.), Europe 2020 -Towards a More Social EU?, Brussels, P.I.E. Peter Lang, 2010.

[14] Premovic J., Arsic Lj., Premovic T., Knowledge Society and KnowledgeBased Economy, 6th Inernational Symposium, Technical Faculty Čacak, Information and Education for the Society of Learing and Knowledge, June, 5, 2011.

[15] Premovic J., Knowledge as a Strategic Potential of Enterprise Development, SM2010, Palic, 2010, pp. 1-11.

[16] Serbia less competitive than EU member states, EU integration since 11.06.2014,

http://www.istmedia.rs/srbija-je-manje -konkurentna-od-clanica-evropskeunije/
[17] Strategy of Scientific and Technological Development of Republic of Serbia for the period 2010-2015. Years - Focus and Partnership, 25.10.2010.

[18] The World Bank; KEI and KI Indexes (KAM 2012). web.worlbank.org/kam.

[19] Tijani A., Statement from 7.03.2014, Irregularly Distributed Innovation, http://www.euinfo.rs/sr/euroservice/11 116/Nepravilno+ raspore\%C4\%91ena +inovativnost.html preuzeto 16.10 . 2014.

[20] World Economic Forum, The Europe 2020 Competitive Report: Building a More Competitive Europe, Geneva, 2012.

[21] World Economic Forum, The Europe 2020 Competitiveness Report, Geneva, 2014;

[22] World Economic Forum, The Global Competitiveness Report 2009-2010, Geneva, 2010;

[23] World Economic Forum, The Global Competitiveness Report 2011-2012, Geneva, 2012; [24] World Economic Forum, The Global Competitiveness Report 2013-2014, Geneva, 2014; 